\title{
TAYANGAN FILM TELEVISI (FTV) PERSPEKTIF PRODUKSI ORGANISASI
}

\author{
Robby Aditya Putra \\ IAIN Curup \\ Email: robbyadityaputra@gmail.com \\ Dede Mercy Rolando \\ UIN Syarif Hidayatullah Jakarta \\ Email: dedemercyrolando@gmail.com
}

\begin{abstract}
ABSTRAK
Kerja tim yang solid dalam memproduksi sebuah program televisi adalah keniscayaan,agar hasil produksi maksimal dan bermakna. Jika proses produksi tidak dijalankan sesuai alur, tentuakan berdampak pada program yang dihasilkan.Mengingat urgensi tersebut, penting mengkaji bagaimana tahapan produksi organisasi dalam pembuatan film televisi.Penelitian inifokus pada produksi organisasi (FTV) "Dzolim" di MNC TV.Untuk membedah kasus tersebut, penulis menggunakan teori Produksi Organisasi Branston dan Stafford. Penelitian ini menunjukkan bahwa meskipun proses produksi tayangan FTV "Dzolim" melibatkan sumber daya manusia, perlatan danbiaya yang maksimal, namun konten FTV Dzolimcenderung tidak natural dan terlalu mendramatisir.
\end{abstract}

\section{Kata Kunci: Komunikasi, Film, Televisi, Organisasi Produksi}

\begin{abstract}
Solid teamwork in producing a television program is a necessity, so that production results are maximum and meaningful. If the production process is not carried out according to the plot, it will certainly have an impact on the program produced. Given the urgency, it is important to examine how the stages of production of the organization in making television films. This research focuses on the production of the organization (FTV) "Dzolim" on MNC TV. To dissect the case, the author uses the theory of production of the Branston and Stafford Organizations. This research shows that even though the production process of "Dzolim" FTV shows human resources, equipment and maximum costs, Dzolim's FTV content tends to be unnatural and too dramatizing.
\end{abstract}

Keywords: Communication, Film, Television, Production Organization 


\section{PENDAHULUAN}

Masyarakat dan informasi bagaikan rekan yang melekat dikehidupan sehari-hari.Kebutuhan masyarakat terhadap informasi semakin meningkat. Untuk memnuhi kebutuhan tersebut, muncul beragam media baru sebagai saluran informasi. Televisi, radio, media sosial adalah beberapa bentuk media penyampai informasi tersebut. Jika dibandingkan dengan media yang lain, televisi mempunyai karaktersitik unik, yaitu mampu memberikan informasi, pendidikan dan hiburan audio-visual kepada khalayak secara serentak (Darwanto Sastro Subroto:1994) Sehingga, televisi mampu mempengaruhi sikap, pandangan dan perasaan pada penonton (Onong Uchjana Effendy:2006).

Organisasi produksi merupakan suatu teknik mencapai kualitas media. Kerja tim yang solid dibutuhkan untuk mencapai tujuan ini. Rangkaian proses produksi mulai dari ide sampai penayangan dirancang sesuai dengan kaidah proses produksi. Proses produksi adalah cara, metode dan teknik untuk menciptakan barang dengan menggunakan sumber-sumber yang ada (Heriyanto:2006). Serta proses kegiatan untuk perancangan SDM, pengembangan, penugasan serta delegasi wewenang untuk tercapainya tujuan bersama (T.Hani Handoko:1984) Sehingga, proses produksi adalah pekerjaan tim bukan individual (Ach.Mohyi:1999).

Melihat bertapa pentingnya proses produksi dalam kelancaran suatu konten, maka penulis memilih MNC TV yang memiliki program-program unggulan yang sedang naik daun karena konsep dan judul-judulnya yang terkesan bombastis dan tak biasa. Dalam hal ini penulis memfokuskan pada tayangan FTV "Dzolim.”

FTV "Dzolim” adalah sinetron religi bertemakan azab dengan judul-judul tayangan yang terbilang bombastis, bahkan mengerikandan mampu menarik perhatian penonton.Film ini tayang setiap hari setiap hari pukul 16.30 WIB dengan judul yang berbeda. Tayangan ini mengandung pesan religi didalamnya, mempertontonkan siksaan Tuhan kepada pemeran antagonis sebagai pionir imaji kisah azab kemalangan sang antagonis dari menjelang ajal hingga dikuburkan. 
Tim produksi yang terlibat dalam pembuatan FTV tersebut sukses booming di televisi dan media sosial. Jalan ceritanya yang menarik berhasil mendapat tempat di hati penonton. Berdasarkan latar belakang di atas, maka penulis menarik pertanyaan Mayor, yaitu Bagaimana tahapan proses produksidalam pembuatan FTV“Dzolim” di MNC TV dalam perspektif produksi organisasi?

Selanjutnya, untuk menjawab pertanyaan mayor tersebut maka dirumuskan beberapa pertanyaan minor, yaitu seperti apa perencanaan di balik pembuatan Film tersebut? Seperti apa proses produksi yang dilakukan oleh tim produksi FTV tersebut? Strategi yang dipakai dalam proses pendistribusian?

\section{PEMBAHASAN}

Sebagai alat analisis akan digunakan perspektif teori Production Organization yang dikemukakan oleh Gill Branston dan Roy Stafford dalam buku the Media Student's Book. Teori ini menjadikan produksi film televisi sebagai contoh kasus. Secara garis besar teori ini menguraikan tahapan proses produksi, yaitu negosiasi singkat, penetapan tema, pra-produksi, produksi, dan pasca produksi (Branston and Stafford:2003) Dari 5 proses produksi, penulis mengambil 3 tahapan dalam produksi yaitu, Sebelum Produksi yang mencangkup penetapan dan negosiasi singkat, Produksi dan Sesudah Produksi. Sehingga dapat menghasilkan produksi yang efektif.

a) Tahap Sebelum Produksi (Pre-Production)

Pra-Productionadalah sebuah prakondisi yang mempersiapkan segala kebutuhan syuting bersifat administrasi maupun tehnik.Persiapan ini dimaksudkan agar kerja produksi di lapangan lebih efisien dari hal waktu, tenaga dan biaya.Serta mekanisme kerja antar kru produksi lebih efektif (Anton Mabruri:2018) Beberapa aspek yang dilakukan sebelum produksi, sebagai berikut; 1) Penelitian (Research)

Penelitian yakni komponen utama produksi.Karena, penelitian bagian penting dari karya media akademik begitu pula produksi, biasanya penelitian datang sebelum negosiasi singkat (Branston and Stafford:2003). Tahap ini dimulai 
ketika menemukan ide atau gagasan, mengumpulkan data, membuat riset dan mengembangkan gagasan menjadi naskah sesuai riset (Darwanto:2011), Selanjutnya menyusun jadwal (timeline) dan meninjau lokasi pengambilan gambar (Morissan:2011).

2) Persiapan (Recce)

Yaitu Persiapan yang baik sangat penting untuk produksi media yang efektif. Dengan melakukan peninjauan baik itu secara teknis dan materil. Tidak kalah penting persiapan lokasi, tata letak kamera dan audiountuk menambah keindahan estetika. Pada tahap ini meliputi pemberesan semua kontrak, perijinan, dan surat menyurat. Latihan para artis dan pembuatan setting, meneliti dan melengkapi peralatan yang diperlukan.Persiapan ini baik diselesaiikan menurut jangka waktu (time schedule) yang sudah ditetapkan (Branston and Stafford:2003).

3) Penataan (Design)

Penataan dalam hal ini editor seni dan sutradara seni akan bertanggung jawab menata elemen-elemen produk-layout yang dramatis pada sebuah film. Desain produk menjadi prioritas utama dalam produksi media (Branston and Stafford:2003). Barang yang akan diperkenalkan dan diproduksi harus ditetapkan dari segi fungsinya. Manajemen biasanya mempunyai beragam pilihan sebagaimana sebuah produk dapat mencapai tujuan fungsionalnya (Dina Febriyana:2003).

Sama halnya Menurut Freed Wibowo, Proses Pra-Produksi dibagi menjadi tiga tahapan yaitu: Penemuan idea/gagasan, Perencanaan meliputi (jadwal/schedule, biaya, penyempurnaan naskah, pemilihan artis, lokasi dan kru). Persiapan meliputi pemberesan semua kontrak, perizinan dan surat menyurat (Freed Wibowo:2007) Setelah tahapan dari pra-produksi ini selesai atau dilakukan secara benar oleh tim, baru bisa melangkah ke tahap pembuatan Film atau tahap produksi itu sendiri.

\section{b) Tahap Produksi (Production)}

Branston dan Stafford mengatakan beberapa penelitian produksi memerlukan keahlian khusus dan pengetahuan, pertama dalam kemampuan 
akademik umum dari penggunaan dan pengecekan sumber daya manusia, kedua dalam kaitannya dengan spesifikasi keahlian khusus (Branston and Stafford:2003). Sama halnya dalam media televisi masing-masing memiliki peran dalam menjadikan sebuah produk konten. Tidak semua sumber daya manusia yang dimiliki organisasi media memiliki keahlian yang sama.

1) Unit dan Peran Produksi

Bebarapa unit diperlukan untuk melakukan proses produksi di perusahaan media. Mulai dari Produser, Sutradara atau Editor, Peneliti, Personal Kreatif, Personal Tekhnik, Freelens, Personal Administrasi, Artis maupun orang yang paham Hukum Produksi siaran (Branston and Stafford:2003). Adapun tugasnya, Sutradara bekerja sama dengan para artis dan crew mencoba mewujudkan apa yang direncanakan dalam kertas dan tulisan (shooting script) menjadi gambar, susunan gambar yang bercerita (Branston and Stafford:2003). Tahap ini, prinsipnya memvisualisasikan konsep naskah (run down) agar dapat dinikmati pemirsa, dimana sudah melibatkan bagian lain yang bersifat teknis.

Agar konsep tersebut dapat dilihat, maka harus menggunakan peralatan (equipment) serta orang (operator) atau lebih dikenal dengan production service (Ciptono Setyobudi: 2006). Pada bagian ini unit-unit organisasi memerankan fungsinya seperti Produsen, Direktur dan Editor, Tenaga teknisi, Tenaga administratif, dan tim kreatif.Adapun hal-hal yang berkaitan dengan konsumen, biasanya merupakan hal dari tim kreatif di balik serangkaian seri program televisi. Selain itu, dalam rekaman suara juga, produser bisa dikatakan sebagai tim kreatif. Adapun dalam hal penerbitan, peran yang sama kemungkinan akan dibagi oleh editor dan manajer produksi (Branston and Stafford:2003).

Sehingga tahap produksi ini membutuhkan persiapan sangat detail beberapa jam sebelum produksi mulai dari rapat kru, reading para pemain dengan tujuan agar para pemain familiar dengan skrip yang diberikan. ${ }^{1}$ Sehingga peran dari unit diatas sangat berperan penting dalam produksi suatu media. 


\section{2) Hak Cipta dan Perizinan}

Produk media sering referensial dan interkstual, memanfaatkan bahan yang direkam sebelumnya. Dalam industri yang sangat komersial hampir apa pun yang dimiliki segala jenis komersial yang potensial, bisa digunakan dalam publikasi lain akan dimiliki dalam hal hak untuk reproduksi. Industri ini telah mengembangkan dokumen khusus untuk produsen media,ini juga digunakan untuk izin (Branston and Stafford:2003). Contohnya penggunaan Sountrack dalam film tersebut harus mendapat izin dari label tersebut.

\section{c) Tahap Setelah Produksi (Post-Production)}

Pasca produksi dimaksud sebagai tahap penyelesaian akhir atau penyempurnaan dari produksi. Tahap penyelesaian meliputi editing baik video maupun audio, pengisian narasi, pembuatan efek khusus, melakukan hasil evaluasi hasil akhir dari produksi.hal itu melibatkan beberapa kegiatan yang berbeda.Branston dan Stafford merancang sebuah langkah akhir dalam pasca produksi sebagai berikut :

1) Penulisan Ulang dan Editing

Setelah shooting selesai, penulis skrip membuat logging yaitu mencatat kembali semua hasil shooting berdasarkan catatan shooting dan gambar. Di dalam logging time code (nomor kode yang dihasilkan dari digit frame, detik, menit dan jam yang dimunculkan dalam gambar) dan hasil pengambilan setiap shoot dicatat (Branston and Stafford:2003). Kemudian berdasarkan catatan itu sutradara membuat editing kasar yang disebut editing offline (Fred Wibowo:2007).

\section{2) Pemeriksaan}

Setelah pengeditan, maka dilakukan pemeriksaan atas naskah atau gambar yang telah diedit untuk memastikan teks mentah tidak terdapat kesalahan ejaan, informasi yang tidak akurat. Dalam hal ini Tim harus mengerti dan menguasai peralatan editing linier maupun nonlinier (Andi Fachruddin:2016). Pekerjaan mereka untuk menemukan kesalahan yang tidak disengaja. Sehingga pemeriksa akan diberikan salinan bukti karya atau hasil karya yang akan diperiksa (Branston and Stafford:2003). 
3) Uji Pemasaran dan Peninjauan

Setelah proses pemeriksaan, dilanjutkan dengan uji pemasaran atau pratinjau terhadap produk yang akan di dikeluarkan. Jika ragu terhadap produk yang diproduksi,maka diperlukan uji pemasaran produk bertujuan untuk melihat respons audien. Meskipun sebagian orang mengatakan langkah ini mengarah ke produk yang lambat (Branston and Stafford:2003).

4) Finishing

Produk media yang paling sukses adalah produk yang berasal dari hasil akhir yang berkualitas. Tampilan yang bagus dengan pemikiran yang diberikan pada pencahayaan dan caption atau katalog yang dicetak dengan hati-hati akan meningkatan audiens. Tahap ini menjadi tahap produksi akhir sebelum produk didistribusikan. Serta melakukan pengecekan terhadap materi yang sudah diedit harus dalam keadaan baik dan memiliki kualitas layak tayang (Branston and Stafford:2003).

Proses produksi ini yang telah dijelaskan diatas merupakan perjalanan panjang yang melewati berbagai tahap, melibatkan berbagai sumber daya manusia dengan berbagai keahlian dan berbagai peralatan serta dukungan biaya dan lain lain.

Sehingga dalam proses pembuatan program televisi hendaknya diperhatikan Standars Operation Procedure (SOP) dalam Pra-produksi, Produksi ataupun Pasca-Produksi, pemahaman hal itu perlu agar proses produksi yang dilakukan oleh organisasi tersebut berjalan efisien dan sukses (Fred Wibowo:2007), Sama halnya pendapat lain mengungkapkan dalam memproduksi program televisi ada standar kerja sebagai acuan dalam proses produksi. SOP produksi dikenal memiliki 3 tahapan, yaitu praproduksi (preproduction), produksi (production), dan pascaproduksi (pascaproduction) (Rusman Latief dan Yusiatie Utud:2015).

Untuk memaparkan permasalahan dalam pembahasan ini, terdapat beberapa konsep qur'ani sebagai pendukung teori yang berkaitan dengan produksi 
organisasi yakni: Pertama, I'dad (Perencanaan) yang berkaitan dengan sebelum produksi. Kedua, Ja'ala (Produksi)yang berkaitan dengan tahap produksi. Ketiga, Ri'ayah(Tanggung Jawab) yakni berkaitan dengan setelah produksi meliputi pendistribusian. Ketiga konsep ini mencangkup produksi organisasi yang berdasarkan Al-quran dan dapat diimplementasikan didalam produksi organisasi agar produksi bisa berjalan efektif dan lancar.

\section{a) I'dad (Perencanaan)}

Manajemen menurut Hadari Nawawi adalah merupakan kegiatan yang dilakukan oleh manager dalam mengurus organisasi, lembaga, maupun perusahaan.Dan tentunya tidak bisa lepas dengan empat komponen yang ada yaitu (POACH) planning, organizing, actuating, dan controlling (Widjaya:1987). Konsep utama dalam perencanaan adalah berpikir secara rasional berdasarkan fakta dan data yang ada guna mewujudkan apa yang hendak dicapainya (Kustadi Suhandang:2007). Ayat al-Qur'an yang menjelaskan tentang suatu perencanaan terdapat dalam surat al-Hasyr ayat 18:

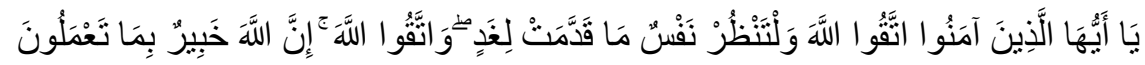

Artinya : "Hai orang-orang yang beriman, bertakwalah kepada Allah dan hendaklah Setiap diri memperhatikan apa yang telah diperbuatnya untuk hari esok (akhirat); dan bertakwalah kepada Allah, Sesungguhnya Allah Maha mengetahui apa yang kamu kerjakan”. (QS. al-Hasyr : 18)

Sehingga dapat disimpulkan bahwa konsep I'dad ini bisa di implementasikan dalam tahapan sebelum produksi, dimana suatu perencanaan atau persiapan dibutuhkan dalam tahap ini untuk kelancaran tahap produksi berikutnya.

\section{b) Ja'ala (Produksi)}

Produksi adalah puncak dari tahapan produksi siaran televisi.Kata Ja'ilun berasal dari kata ja'ala artinya menciptakan atau menjadikan atau memproduksi. Menurut ibnu katsir "sesungguhnya aku hendak menjadikan seorang khalifah di bumi” yakni suatu kaum yang akan menggantikan satu kaum lainnya, kurun demi kurun dan generasi demi generasi (Al Imam Abu Fida Ismail Ibnu Katsir Ad Dimasyqi:2000). 
Al-Quran surat Al-Baqoroh ayat 30 yang menjelaskan bahwa "sesungguhnya aku hendak menjadikan (khalifah) di muka bumi" mereka berkata: “mengapa Engkau hendak menjadikan (khalifah) dibumi itu orang akan membuat kerusakan padanya dan menumpahkan darah, padahal kami senantiasa bertasbih dan emmuji Engkau dan mensucikan Engkau?" Tuhan berfirman: "sesungguhnya Aku mnegetahui apa yang kamu tidak ketahui"

Sehingga dari ayat tersebut dijelaskan bahwa Allah SWT menginginkan manusia menjadi khalifah di bumi dan bertanggung jawab. Tanggung jawab juga berarti berbuat sebagai perwujudan kesadaran akan kewajibannya (Winardi:2006), Sehingga hal ini Ja'ala (Produksi) yakni berkaitan dengan tahapan inti yaitu produksi dimana dalam tahap ini bertujuan untuk menvisualisasikan konsep agar bisa dinikmati audiens yang dilaksanakan oleh unit unit kerabat kerja yang bertugas. Konsep tersebut juga dapat diimplementasikan guna kelancaran suatu produksi konten FTV Dzolim.

\section{c) Ri'ayah (Tanggung Jawab)}

Ri'ayah atau Tanggung jawab merupakan kesadaran manusia akan tingkah laku dan perbuatan yang disengaja maupun yang tidak disengaja. Tanggung jawab juga berarti berbuat sebagai perwujudan kesadaran akan kewajibannya (Winardi:2006). Pendapat lain mengatakan tanggung jawab merupakan konsekuensi penting dalam sebuah organisasi yang ditentukan melalui garis-garis kewenangan maupun garis perintah (Erni Trisnawati dan Kurniawan Saefullah:2012). Sebagaimana firman Allah dalam surat al-Nisa ayat 58 menjelaskan :

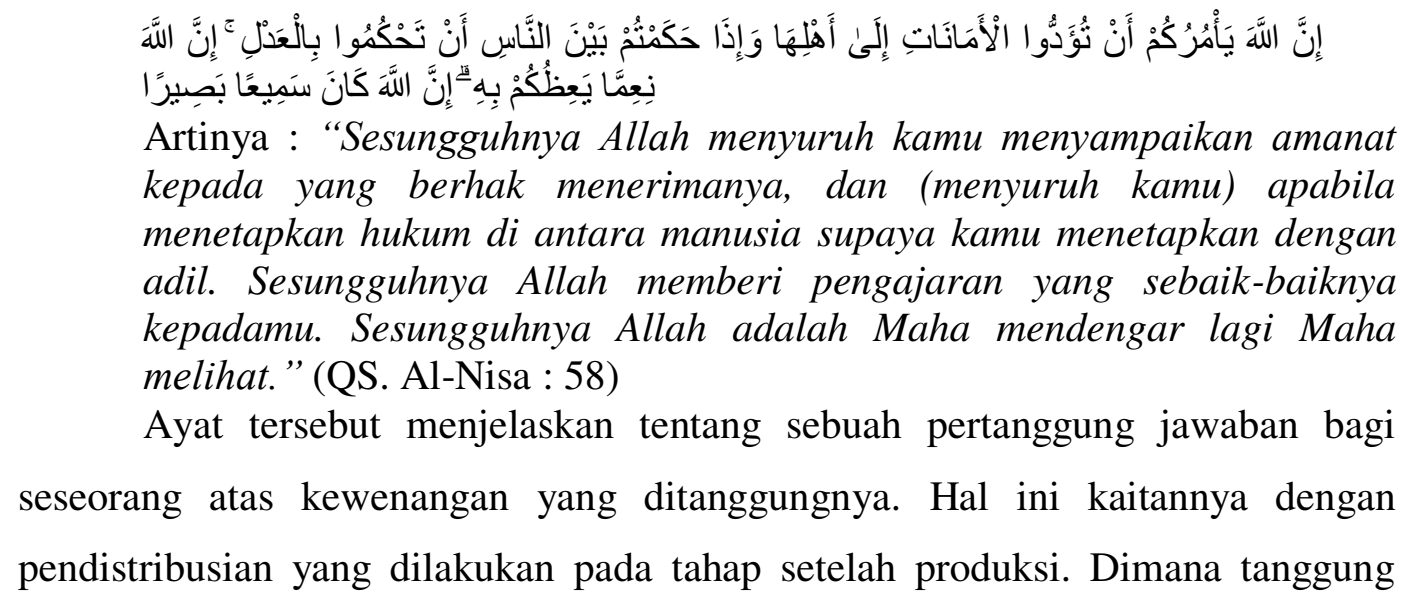
kepada yang berhak menerimanya, dan (menyuruh kamu) apabila menetapkan hukum di antara manusia supaya kamu menetapkan dengan adil. Sesungguhnya Allah memberi pengajaran yang sebaik-baiknya kepadamu. Sesungguhnya Allah adalah Maha mendengar lagi Maha melihat." (QS. Al-Nisa : 58)

Ayat tersebut menjelaskan tentang sebuah pertanggung jawaban bagi seseorang atas kewenangan yang ditanggungnya. Hal ini kaitannya dengan pendistribusian yang dilakukan pada tahap setelah produksi. Dimana tanggung 
jawab sampai akhir penyelesaian konten atau pendistribusian merupakan suatu kewajiban bagi tiap unit unit kerabat kerja yang bertugas dalam FTV Dzolim.

Dalam hal ini bisa diartikan bahwa, pendidikan dan praktik pembelajaran telah memiliki perkembangan konsep sebagai fokus studi penelitian dan termasuk sebuah teori, pemikiran konsep, pendekatan saintifik, model, strategi, metode dan evaluasi . Islam adalah agama yang memiliki pronsip dan ajaran filosofi yang sempurna dan banyak pengganutnya Sehingga diharapkan apapun penelitian yang akan dibahas memiliki konsep metodologis berdasarkan ajaran islam al-quran dan sunnah yang dikolaborasikan dengan teori yang sudah ada.

Konsep dalam pembahasan ini, merupakan konsep yang sesungguhnya ada dalam ajaran Islam, yang berkaitan dengan teori Produksi Organisasi yang didalamnya membahas tahapan produksi.Seorang peneliti akan memperhatikan sejauh mana pengaruh sebuah ajaran, doktrin, organisasi, institusi atau da'I terhadap masyarakat. masyarakat tersebut akan dibandingkan bagaimana keadaan sebelumnya dengan keadaan sesudah mengikuti suatu program tertentu (Bakti:2005).

Hal ini berarti antara konsep Qur'ani dan teori komunikasi dapat dikomperasikan atau dihubungkan. Akan tetapi tidak semua studi ataupun kajian penelitian berkeinginan untuk mengkomninasikan antara konsep qur'ani dan teori komunikasi. Seperti yang diungkapkan oleh Andi Faisal Bakti, "Ketika menulis tentang komunikasi dan perkembangannya di Indonesia, hal ini sangat krusial jika dilihat relegiusnya dalam sebuah peristiwa (Bakti:2000).

Segala bentuk penyampaian dalam penelitian bisa dijadikan dakwah dilihat dalam kacamata Islam. Sesungguhnya dakwah adalah aturan utama untuk bisa menetapkan pemahaman religius manusia (Bakti:2015), Kata dakwah berasal dari kata da'a, yang diperoleh dari pikiran Al-Quran, Sunnah dan Ulama.Artinya adalah mengajak, memanggil, mendoakan dan bisa propaganda (Bakti:2011). Dalam hal ini dapat dikatakan bahwa dakwah juga bisa melalui film.

Untuk itu dakwah harus dikemas dengan cara yang menarik dan tampil secara aktual, faktual, dan kontekstual. Aktual berarti dapat memecahkan maslahmasalah yang kekinian dan hangat ditengah masyarakat.Faktual berarti konkrit 
dan nyata, sedangkan kontekstual dalam arti relevan dan menyangkut problem yang sedang dihadapi oleh masyarakat (Bakti:2013).

Pendidikan dan praktik pembelajaran telah memiliki perkembangan konsep sebagai fokus studi penelitian dan termasuk sebuah teori, pemikiran konsep, pendekatan saintifik, model, strategi, metode dan evaluasi. Islam adalah agama yang memiliki pronsip dan ajaran filosofi yang sempurna dan banyak pengganutnya (Bakti:2011), Sehingga diharapkan apapun penelitian yang akan dibahas memiliki konsep metodologis berdasarkan ajaran islam al-quran dan sunnah yang dikolaborasikan dengan teori yang sudah ada.

\section{ANALISIS}

Mengacu pada teori organisasi produksi milik Gill Branston dan Roy Stafford yang menyatakan bahwa dalam produksi suatu konten, prosesnya melalui 3 tahapan yang saling berhubungan, penulis akan menghubungkannya dengan proses produksi konten tayangan sinetron FTV Dzolim di MNCTV.

Branston menjelaskan bahwa tahap pertama merupakan tahap pra produksi yang terdiri dari penemuan gagasan/ide, peninjauan, dan desain program.Tahap pertama ini terjadi ketika para pencari konten membuat "catatan kasar" baik yang bersumber dari peristiwa atau kejadian nyata.Tahap kedua merupakan tahap pelaksanaan produksi yakni memvisualisasikan konsep naskah atau run down agar dapat dinikmati pemirsa. Tahap ketiga yaitu pasca produksi dimana para pengolah hasil konten yang telah dibuat bersama tim produksi telah diedit dan layak untuk ditayangkan untuk dinikmati audiens, tahap ini disebut juga pendistribusian yang melibatkan production house.

Pada tahapan ini, prinsipnya memvisualisasikan konsep naskah atau run down agar dapat dinikmati pemirsa, dimana sudah melibatkan bagian lain yang bersifat teknis.Karena konsep tersebut agar dapat dilihat harus menggunakan peralatan (equipment) yang sudah pasti ada orang (operator) terhadap peralatan tersebut agar dapat beroprasi atau lebih dikenal dengan production service (Ciptono Setyobudi:2006). Berikut ini adalah proses produksi yang dilalui oleh tim produksi FTV "Dzolim." 


\section{1) Perencanaan Produksi Sinetron FTV "Dzolim"}

Pra-produksi merupakan tahap paling penting dalam sebuah produksi televisi.Pra-Production (sebelum produksi) disini adalah sebuah prakondisi yang mempersiapkan segala kebutuhan syuting baik bersifat administrasi maupun tehnik.Persiapan produksi ini dimaksudnkan agar kerja produksi di lapangan lebih efisien dalam hal waktu, tenaga dan biaya.Serta mekanisme kerja antar kru produksi lebih efektif.

Pada tahapan ini juga merupakan proses awal penemuan ide/gagasan yang kemudian dikerjakan sebagai kegiatan untuk menghubungkan ke berbagai data yang diperlukan. Bahan-bahan yang terkumpul kemudian dirangkai oleh penulis naskah menjadi suatu naskah, sesuai dengan format program yang telah ditentukan.

Layaknya produksi lainnya, FTV "Dzolim" terlebih dahulu melalui tahapan sebelum akhirnya ditonton oleh masyrakat melalui media televisi. Tahapan tersebut dimulai dari tahapan perencanaan sebelum produksi, tahap produksi dan setelah produksi.Dalam sebuah proses produksi produksi program televisi, keberhasilan sebuah produksi program televisi sangat ditentukan oleh keberesan tahap perencanaan dan persiapan. Oleh karena itu, pada tahap ini harus dilaksanakan dengan sebaik-baiknya agar dalam tahap produksinya pun berjalan dengan baik dan lancar (Darwanto:2007).

a) Analisis Ide Cerita

Dalam FTV “Dzolim”, tahap perencanaan produksi dimulai dari penemuan ide tau gagasan. Penulis naskah FTV 'Dzolim' produksi MNC Pictures, Henny Puspita (39) dan Nazaruddin Thamrin (51),serta Ruslan Ghofur (37).memberikan gambaran proses kreatif di balik tayangan sinetron 'Dzolim', dari menemukan ide hingga menjadi judul dengan adegan yang dinilai bombastis.Henny merupakan pemain baru di dunia script writing. Dia mendalami dunia kepenulisan tiga tahun terakhir ini. Sementara, Nazaruddin sudah menggeluti bidang ini sejak tahun 1990-an. Selain 'Dzolim', ia juga menulis untuk serial lain. wawancara penulis naskah FTV Dzolim Nazaruddin oleh Republika pada Tanggal 23 November 2018 . 
Sumber inspirasi cerita untuk 'Dzolim', ada pola yang sama. Kedua penulis ini mengatakan, ide berasal dari lingkungan sekitar.Misalnya, terinspirasi dari insiden kecelakaan atau orang yang meninggal jatuh dari pohon.Tetapi ide itu juga bisa berasal dari curi dengar dari percakapan orang ataupun membaca buku serta memperhatikan kejadian yang ada di sekitar. Hanya saja, yang membedakan adalah level imajinasi yang dituangkan dalam tulisan. Dilanjutkan pematangan konsep agar idea tau gagasan siap di produksi.Dalam hal ini para penulsi naskah menyulap naskah menjadi naskah yang menarik namun tidak terlepas dari naskah aslinya.Dengan merevisi alur logika dari sebuah cerita. Untuk adegan yang liar, jika tidak memungkinkan dan tidak logis, maka akan dihapus dari naskah. wawancara dengan penulis naskah FTV Dzolim Henny oleh Republika pada Tanggal 23 November 2018.

Tulisan yang dibuat dituang semenarik mungkin, harus melihat sisi lain dari sebuah cerita yang sebelumnya tidak terbayang oleh pemirsa dalam mereka adegan. Tujuannya, penonton menjadi lebih betah menyaksikan tayangan karena terbius dengan 'hal yang ajaib' di layar. Kemudian kedua penulis ini mengirimkan ide naskah berdasarkan apa yang ingin mereka angkat. Akan tetapi, pihak MNC Pictures merekomendasikan agar mengirimkan naskah dengan isi azab yang kejam karena ratingnya yang tinggi.

Hal ini juga termasuk dengan materi produksi dalam idea tau gagasan. Materi produksi dalam FTV ini disebut juga isi cerita yang dikembangkan dari ide yang ditemukan di awal.Materi produksi ditentukan oleh penulis sknario.Penulis sekenario berusaha mamasukan agar setiap scane ada pengajaran agama (Islam) sehingga penulisan skenario harus mulai cari-cari dalilnya. Setelah itu barulah mereka membreakdown naskah tersebut untuk mempelajari secara rinci cerita yang akan dibuat film.

Randi menjelaskan, MNC Pictures sendiri menggandeng beberapa production house $(\mathrm{PH})$. Penulis bisa mengirimkan naskah ke beberapa $\mathrm{PH}$ yang ditunjuk.Barulah PH mengirimkan ke pihak MNC. Setelah disetujui, naskah akan direvisi sesuai dengan keputusan rapat sutradara. Biasanya, revisi meliputi peringkasan adegan karena durasi yang terbatas. Atau tambahan lainnya sesuai 
dengan kebutuhan saat proses syuting, wawancara dengan asisten sutradara FTV Dzolim Randi Pratama oleh Republika pada Tanggal 23 November 2018.

b) Menyusun Jadwal dan Budgeting

Berdasarkan data yang penulis dapatkan setelah pembauatan naskah cerita selanjutnya mereka mencari lokasi yang pas untuk di jadikan lokasi shooting.Hal ini tidak semerta merta asal pilih. Mereka melakukan survey ke beberapa tempat dan melakukan perbandingan serta membuat surat ijin tertentu.

Pencarian lokasi ditentukan oleh sutradara dan kru.Dengan pertimbangan, lokasi yang menjadi pilihan dipertimbangkan mampu menyesuaikan seleuruh scane yang tertulis di dalam scenario. Dalam produksi FTV "Dzolim" lokasi yang dipilih beragam atau berbeda atau bahkan bisa sama lokasinya hanya pemilihan rumah nya yang dibedakan agar tidak sama persis dengan episode sebelumnya. Mengingat bahwa tayngan ini sinetron FTV kejar tayang jadi pemilihan lokasi tidak berjauhan secara signifikan, namun terkadang memilih di puncak atau perdesaan, wawancara dengan asisten sutradara FTV Dzolim Randi Pratama oleh Republika pada Tanggal 23 November 2018. Berdasarkan data yang penulis dapatkan bahwa dalam hal ini mereka harus memperhatikan mulai dari transportasi, keamanan, sumber listrik, dll.

Mengenai biaya produksi itu tanggung jawab produser. Seperti yang dijelaksan oleh Branston dan Stafford produser berwenang dalam pemberi dana anggaran belanja dan pengatur sumbernya (Branston and Stafford:2003). Produser pelaksaa mengetahui berapa harga jual dari sebuah hasil produksi, karena alasan itu biaya diatur seluruhnya oleh pimpinan produksi dan produser pelaksana agar pengeuaran tidak melebihi budget yang telah ditentukan perusahaan, wawancara dengan asisten sutradara FTV Dzolim Randi Pratama oleh Republika pada tanggal 23 november 2018 .

c) Persiapan

Dalam hal ini persiapan seperti kostum pakaian yang sesuai dengan naskah harus dilakukan oleh tim kreatif. Serta persiapan alat alat yang menunjang proses shooting seperti sarana dan prasarana yang menunjang.Sarana dan prasarana merupakan peralatan yang memadai, tentu saja yang diperlukan kualitas alat 
sesuai standart broadcast yang mampu menghasilkan gambar dan suara yang bagus. Kepastian adanya peralatan itu mendorong kelancaran seluruh proses produksi. Dimana pengembangan dan jumlah tergantung pada program yang akan diproduksi.

Sebuah proses produksi memerlukan berbagai sarana penunjang produksi yang sangat penting untuk diperhatikan, yaitu unit peralatan gambar,cahaya dan suara. Adapun unitnya diantaranya: Kamera, Tripod, VTR, Lighting, Stereofoem, Mic boom, Audio Mixer, Genset, Sarana Transportasi, Tiang dan Kabel untuk keperluan tertentu. Serta prasarana yang digunakan dalam proses produksi ini adalah: ruang meeting, ruang editing, ruang mastering dan property shooting. wawancara dengan asisten sutradara FTV Dzolim Randi Pratama oleh Republika pada tanggal 23 november 2018

d) Pemilihan Artis atau Talent

Setelah sekenario berhasil dirampungkan, proses selanjutnya adalah pencarian pemain yang dilakukan oleh sutradara. Karena setiap judul beda pemain, maka naskah disesuaikan dengan pemainnya. Hal ini juga melibatkan sutradara, penulis naskah, produser serta tim kreatif untuk pematangan konsep, bagaimana format cerita yang akan disajikan.Setelah tahapan perencanaan yang disebutkan di atas telah dilalui, kemudian barulah proses pengambilan gambar dilakukan.

Setelah ditemukan artis yang sesuai dengan karakater tokoh dalam cerita, tahapan berikutnya adalah penentuan kru produksi.Tidak berbeda dengan penentuan pemain, penentuan kru produksi pun dilakukan sepenuhnya oleh sutradara. Alasannya karena untuk kenyamanan karna suatu tim harus memiliki rasa respect serta kompak.

Diketahui pula FTV Dzolim ini melibatkan sutradara yang berbeda-beda pada tiap episodenya.Berdasarkan data yang penulis dapatkan dilapangan bahwa salah satu judul FTV Dzolim yang viral untuk episode Mandor Kejam mati Terkuburdi Cor-coran dan Tersambar Meteor bangku sutradara diduduki oleh Solihin.Lalu adapula M.Irwan Arwana yang juga memyutradarai episode Wanita Agen PRT Suka Menyiksa Matinya Karena ledakan Tabung Gas. wawancara 
dengan asisten sutradara FTV Dzolim Randi Pratama oleh Republika pada tanggal 23 november 2018

Atas dasar itulah, sutradara harus menrasa nyaman dengan orang-orang yang berkerja sama. Proses pengambilan gambar adalah kerja tim yang membutuhkan kekompakan dan kenyamanan. Maka, sutradara berhak menentukan siapa saja untuk menjadi rekan kerjanya untuk menghasilkan tontonan yang bagus.Dalam perencanaan ini, kru yang terlibat dalam produksi terdiri dari: asisten sutradara, kalper, pencatat time, soundman, lightingman, camera person, piñata artistic, pengarah lapangan dll.

\section{2) Proses Shooting FTV "Dzolim" di MNC TV}

Setelah perencanaan selesai, langkah berikutnya adalah produksi atau proses pengambilan gambar atauShooting. Namun, sebelum dilakukan proses pengambilan gambar dilakukan beberapa persiapan. Persiapan seluruh peralatan dimulai sebelum produksi.Orang orang yang bertanggung jawab atas peralatan mengatur semua keperluan shooting dan menuliskan nya didalam daftar peralatan. Selain daftar peralatan juga dibuat daftar properties yang berisi barang-barang atau alat-alat yang dibutuhkan sebagai sarana penunjang yang dibutuhkan selama proses pengambilan gambar.

Sebelum melakukan proses shooting para kru menyiapkan set yang sesuai dnegan scenario. Sutradara mengarahkan para kru untuk menata set serta mengetes kualitas suara mic. Para kru menyiapkan alat sesuai dnegan yang menjadi tanggung jawab.

Hal menarik dalam proses produksi disini adalah satu rumah bisa digunakan untuk lokasi pengambilan lebih dari satu tokoh dan ditata sedemikian rupa agar menyerupai tuntunan scenario. Selain itu, lokasi yang didalmnya kenyataannya merupakan sutau ruang tertentu bisa disulap menyerupai ruang lainnya sesuai kebutuhan skrenario.Disinilah personal kreatif seperti yang dijelaskan Branston dan Staffod dibutuhkan.

Setelah set selesai ditata, tahap selanjutnya latihan para pemain. Dipantau oleh sutradara.Setelah latihan dirasa cukup, peralatan dianggap siap, lalu pengambilan gambar dilakukan.Untuk pengambilan setting indoor atau outdoor 
pada tiap episode dominan pada pengambilan didalam atau luar ruangan dengan pertimbangan berbagai hal data diperoleh dari wawancara dengan asisten sutradara FTV Dzolim Randi Pratama oleh Republika pada tanggal 23 November 2018

\section{3) Strategi Pendistribusian oleh Tim Produksi FTV Dzolim}

Setelah proses produksi di lapangan selesai, langkah selanjutnya adalah proses editing. Editing adalah pekerjaan mmemotong-motong dan merangkaikan atau menyambung potongan-potongan gambar sehingga menjadi film yang dimengerti. Proses editing dikenal dalam dua langkah, yakni editing offline dan editing online (Askurifai Baksin:2006). Proses editing yang dilakukan oleh FTV "Dzolim" sama dengan proses rumah produksi lainnya.

Namun, ada hal yang menarik dalam pasca-produksi FTV "Dzolim" ini yaitu pada proses pendistribusiannya. Yang tidak terduga dari proses produksi film ini adalah ada tim khusus yang membuat konten agar viral di sosial media. Asisten sutradara Randi Pratama adanya PH atau Production House sendiri yang membuat konten itu viral di media sosial. Sehingga FTV tersebut mendapatkan rating tertinggi di akhir tahun ini Seperti official Youtube, Twiter dan Facebook. wawancara dengan asisten sutradara FTV Dzolim Randi Pratama oleh Republika pada Tanggal 23 november 2018.

Ruslan sebagai penulis naskah pada FTV Dzolim menambahkan bahwa viralnya konten hasil sknario para penulis naskah, karena pihak mereka memiliki akun media sosial yang berhasil membuat konten itu viral di media sosial, dan ini juga merupakan salah satu strategi pendistibusian mereka. Melihat banyaknya antusias serta pandangan dari para penonton yang tertarik dengan tanyangan tersebut akhirnya membuat production house khsusus untuk membuat tayangan sinetron ini semakin dinantikan,wawancara dengan penulis naskah FTV Dzolim Ruslan Gofur oleh Republika pada Tanggal 23 November 2018.

\section{KESIMPULAN}

Dari paparan diatas, disimpulkan bahwa dalam memproduksi film religi di televisi agar sampai kepada pemirsa, Tim produksi FTV Dzolim di MNCTV melakukan 3 tahapan produksi yang saling berkaitan. Tahap Sebelum Produksi 
terjadi ketika para pencari konten membuat materi kasar menjadi bahan konten keislaman.Tahap Produksi terjadi ketika para pengolah konten merubah naskah menjadi suatu karya film yang dibantu oleh unit unit yang bertugas. Tahap Setelah Produksi menggabung-gabungkan bahan itu menjadi hasil akhir untuk di editing sampai dengan pendistribusian. Seluruh proses produksi tersebut tentunya dilakukan oleh kerja sama seluruh tim dengan memperhatikan kewajibannya masing-masing.

Adapun strategi yang digunakan dalam memproduksi siaran FTV Dzolim ini adalah penyajian tayangan serta membuatan judul yang terkesan bombastis atau diluar nalar bisa dibilang Hyperbola atau berlebih-lebihan. Namun, dalam hal ini justru yang membawa tayangan tersebut cenderung tidak natural dan terlalu mendramatisir.

Terdapat pula konsep Qur'ani sebagai pendukung teori dalam pembahasan ini, terdapat beberapa konsep qur'ani sebagai pendukung teori yang berkaitan dengan produksi organisasi yakni: Pertama, I'dad (Perencanaan) yang berkaitan dengan tahap sebelum produksi. Kedua, Ja'ala (Produksi) berkaitan dengna tahap produksi.Ketiga, Ri'ayah (Tanggung Jawab) yang berkaitan dengan tahap setelah produksi sampai ke pendistribusian.

Penellitian ini menegaskan bahwa suatu proses produksi sejatinya dapat berhasil menampilkan konten yang ideal jika seluruh pihak-pihak yang terkait didalamnya saling bersinergi, bekerjasama dan bertanggung jawab terhadap pekerjaannya selama proses produksi itu berlangsung (Pra-Production, Production dan Post-Production).

\section{DAFTAR PUSTAKA}

Al-Quran dan Terjemahan. 2014.Almummayyaz Tajwid, Transliterasi dan Terjemah. Jawa Barat: Cipta Bagus Segera.

Al Imam Abu Fida Ismail Ibnu Katsir Ad Dimasyqi.2000. Tafsir Ibnu Katsir Juz 1 AlFatihah-Al-Baqarah. Bandung: Sinar Baru Al Gensindo.

Baksin, Askurifai. 2006. Jurnalistik Televisi Teori dan Praktik. Bandung: Simbiosa Rekatama Media.

Bakti, Andi Faisal. 2000. Communication Parallel in the Influence of Religius Values in the Development of Japan and Indonesia. Review of Human Factor Studies, Vol.6, 1 (June) Canada. 
Bakti, Andi Faisal. 2005. Mengkaji Islam Sebagai Objek Ilmu Pengetahuan:Tinjauan Interdispliner Komunikasi. Petra, Vol.VII,No.2.

Bakti, Andi Faisal. 2011. Southeast Asia, Islamic Dakwah in.Oxford Journal. New York: Oxford Press.

Bakti, Andi Faisal. 2011. The Role of Islamic Media in the Globalization Era.

Bakti, Andi Faisal. 2013. "Trandsetter Komunikasi di Era Digital: Tantangan dan Peluang Pendidikan Komunikasi dan Penyiaran Islam”, Jurnal Komunikasi Islam, Vol. 02, No. 01

Bakti, Andi Faisal. 2015. Applied Communication to Dakwah for Peace .

Bakti, Andi Faisal. 2015. Bio-Communication Through Social Media Facebook on Education Practice. Indonesia: UNESCO en Communication ORBICOM.

Branston, Gill dan Roy Stafford. 2003. The Media Student's Book . London and New York: Roudledge.

Effendy, Onong Uchjana. 2006. Ilmu Komunikasi Teori dan Praktek. Bandung: Remaja Rosdakarya.

Erni Trisnawati \& Kurniawan Saefullah. 2012. Pengantar Manajemen. Jakarta : Kencana.

Fachruddin, Andi. 2012. Dasar-Dasar Produksi Televisi edisi-1. Jakarta: Prenada Media Group.

Fachruddin, Andi. 2016. Menejemen Pertelevisian Moderen. Yogyakarta: CV.ANDI OFFSET.

Fachruddin, Andi. 2017. Dasar-Dasar Produksi Televisi . Jakarta: Prenemedia Group.

Febriyana, Dina. 2003. "eJurnal Komunikasi, 2003, ilkom.fisip.unmul.ac.id.ISSNO00000 , volume 1 no.4.

Handoko, T.Hani. 1984. Menejemen edisi 2. Yogyakarta: BPFE.

Heriyanto. 2006. Produksi Acara Televisi .Yogyakarta: Diklat Ahli Multi Media MMTC.

Latief, Rusman dan Yusiatie Utud. 2015. Siaran Televisi Non Drama (Kreatif, Produksi, Public Relation dan iklan). Jakarta: Prenadamedia Group.

Mabruri, Anton KN. 2018. Panduan Acara Produksi TV Drama .Jakarta: Gramedia.

Mohyi, Ach. 1999. Teori dan Prilaku Organisasi. Malang: UMM Press.

Morissan.2011. Manajemen Media Penyiaran. Jakarta: Kencana.

Setyobudi, Ciptono. 2006. Teknologi Beoadcasting TV . Yogyakarta: Graha Ilmu.

Subroto, Darwanto Sastro. 1994. Produksi Acara Televisi. Yogyakarta: Duta Wacana University Press.

Subroto, Darwanto Sastro. 2007. Televisi sebagai Media Pendidikan Cet.ke-1. Yogyakarta: Pustaka Pelajar.

Subroto, Darwanto Sastro. 2011. Televisi Sebagai Media Pendidikan. Yogyakarta: Pustaka Pelajar.

Suhandang, Kustadi. 2007. Manajemen Pers Dakwah Dari Perencanaan Hingga Pengawasan. Bandung : MARJA.

Wibowo, Freed. 2007. Teknik Produksi Program Televisi. Yogyakarta: Pinus.

Widjaya, AW. 1987. Perencanaan Sebagai Fungsi Manajemen. Jakarta: PT. Bina Aksara.

Winardi.2006. Teori Organisasi dan Pengorganisasian.Jakarta: PT Raja Grapindo Persada. 